\title{
Two fatalities in Durban's multiple hospital strikes
}

Two strikers, believed to be cleaners, died in a confrontation with security guards at King Edward VIII Hospital on 14 July, following the non-implementation of a legal amendment rendering certain non-timebased temporary hospital staff permanent employees.

The South African Public Service Union (SAPSU) vowed on 16 June to extend its week-long protest, demanding that temporary workers employed for longer than 3 months at government institutions be given permanent jobs. The strikes affected Mahatma Gandhi, King Dinizulu and King Edward VIII hospitals. The pre-dawn killing involved security guards and an allegedly armed cleaner who approached them at the hospital. The cleaner and a colleague were shot, one body being found by police at the scene and another nearby.

Speaking at a press briefing on 16 June, the interim secretary-general of the union, Moses Tsotetsi, said the legal section in dispute was the amendment to Section 198 of the Labour Relations Act (Act 66 of 1995), which dealt with temporary workers. He said the law, which was officially signed in, needed enforcing, with no bargaining council involvement. 'Workers are unwilling to back down - they're tired,' he said. Many of those affected were security guards and cleaners younger than 40, and legally entitled to a salary of between ZAR5 000 and ZAR6 000, plus benefits. This would increase to the level of government employees after 18 months. While it was not their intention to impact on essential health services, they had to fight for their rights and were consulting lawyers. Led by former COSATU secretary-general Zwelinzima Vavi, SAPSU protestors marched to the Durban City Hall to deliver a memo to KwaZulu-Natal (KZN) premier Willies Mchunu. A spokesman for the KZN health department was unavailable.

Chris Bateman

chrisb@hmpg.co.za

S Afr Med J 2016;106(9):849.

DOI:10.7196/SAMJ.2016.v106i9.11335 